Cell and Organ Transplantology. 2020; 8(1):76-80.

doi: $10.22494 /$ cot.v8i1.107

\title{
Stem cells transplantation in the treatment of patients with cerebral palsy
}

\author{
Petriv T. ${ }^{1,2,3}$, Tatarchuk M. ${ }^{1}$, Tsymbaliuk Ya. ${ }^{1}$, Tsymbaliuk Yu. ${ }^{1}$, Tsymbaliuk V. ${ }^{4}$ \\ ${ }^{1}$ Romodanov State Institute of Neurosurgery of the National Academy of Medical Sciences of Ukraine, \\ Department of Reconstructive Neurosurgery with X-ray surgery, Kyiv, Ukraine \\ ${ }^{2}$ Medical Center Hemafund, LTD, Kyiv, Ukraine \\ ${ }^{3} \mathrm{QR}$ Health Solutions, Kyiv, Ukraine \\ ${ }^{4}$ National Academy of Medical Sciences of Ukraine, Kyiv, Ukraine \\ e-mail: petrivtaras@gmail.com
}

\section{ABSTRACT}

Cerebral palsy remains a significant problem today, despite scientific and technological progress. The high degree of disability and unsatisfactory quality of life of patients in this category, necessitates the search for and implementation of the latest treatments, one of which is cell transplantation. The use of regenerative cell technologies in the treatment of patients with cerebral palsy is extremely promising. Numerous experimental studies have significantly expanded the understanding of the mechanisms of the effect of the use of stem cells in cerebral palsy. Clinical applications of stem cells of different origins are safe, which is one of the prerequisites for continuing research in this area.

This review is devoted to the use of regenerative cell technologies in the treatment of cerebral palsy, the current state and prospects of the approach to the treatment of cerebral palsy with stem cells.

KEY WORDS: stem cells; cell therapy; cerebral palsy

Despite advances in perinatal medicine, complications during pregnancy and childbirth remain a significant problem today. Premature birth and asphyxia of newborns are the most common complications that lead to CNS damage, manifested by a group of diseases that are combined under the name of cerebral palsy (CP).

Cerebral palsy is a group of diseases of the nervous system, the manifestation of which is disorders of movement, balance and body position. It occurs due to malformations of the brain or damage to its parts that control muscle tone and motor activity. Most motor disorders accompanied by mental retardation, seizures, respiratory failure, digestion, bladder and bowel disorders, eating difficulty, skeletal deformities, hearing and vision problems, which in future will form a behavioral disorder and learning difficulties [1].

Cerebral palsy is one of the most common causes of childhood disability: the rate in Europe is from 2 to 4 per 1,000 live births, in Ukraine 2.56 per 1,000 live births. Among extremely preterm infants, the number of cases of cerebral palsy has increased to $40-100$ per 1,000 live infants $[1,2]$. Cerebral palsy belongs to a group of multifactorial diseases. The main etiological factors are perinatal and intranatal hypoxia, asphyxia, intrauterine infection, genetic disorders, immunopathological changes in CNS, multiple pregnancy $[3,4]$.

An important pathogenetic mechanism in cerebral palsy, which determines the degree of intrauterine brain damage, is the autoimmune process. Due to the influence of a number of the above etiological factors of the perinatal period, which cause intrauterine damage to the fetus, the destruction of brain structures occurs. The products of destruction can enter the circulatory system as foreign substances - brain antigens. They cause the formation of antibodies. Thus, there is an autoimmune process with the alteration of brain tissue [5].

The treatment of cerebral palsy is a difficult problem, as there is no single approach to the correction of motor deficit and cognitive impairment at the moment. A lot of different methods of treatment, both surgical and conservative, have been proposed, each of these methods has its drawbacks $[6,7]$. This fact explains the growing interest of researchers in the use of immunomodulatory and neuroprotective properties of stem cells (SCs) $[8,9]$.

\section{THE CHOICE OF STEM CELLS SOURCE}

Previous studies have shown the effectiveness and developed an algorithm for neurosurgical treatment of patients with cerebral palsy using embryonic stem cells, taking into account their age and features of the disease. Faster recovery of the movement apparatus, prevention of development of irreversible changes in muscular and joint structures is proved [10-15]

Embryonic stem cells (ESCs), which have unlimited potential for selfreproduction and differentiation, are extremely promising, but, on the other hand, it is these properties that make them dangerous in terms of oncogenicity [16]. In addition, the separation of the ESCs from the embryo presupposes its death and raises moral and ethical issues.

Another type of SCs that are similar in properties to embryonic ones is induced pluripotent stem cells (iPSCs). The essence of their production is to isolate the cells of the adult organism (usually a dermal fibroblast) and return it to the embryonic state through the action of transcription factors (special proteins or miRNAs). In 2008 Japanese biologist Yamana- 
ka S. proved for the first time that this requires only 4 transcription factors OCT4, C-MYC, SOX2, KLF4 [17], for which he received the Nobel Prize in 2012. It was later found that iPSCs, as well as ESCs, have oncogenic properties and the epigenetic memory, inherent in them, makes the effect of their use unpredictable [18]. Therefore, neither ESCs nor iPSC are optimal candidates for widespread clinical use.

Umbilical cord blood is a rich source of stem cells and can be collected at birth, with the possibility of storage in public or private banks and use in the future. Umbilical cord blood contains the most hematopoietic stem cells (HSCs), mesenchymal stem/stromal cells (MSCs) and endothelial progenitors (EPs) [19]. The obtaining of umbilical cord blood SCs is simple, fast and does not raise any moral and ethical issues. In addition, they have low immunogenicity and are not rejected at incomplete compatibility of the donor and recipient in the system of leukocyte antigens HLA (human leukocyte antigen) [20]. The reason for this is the immature immune system of the fetus. For therapeutic purposes, the mononuclear fraction of umbilical cord blood is used, which contains, in addition to the above types of SCs, immunoregulatory T-lymphocytes. Today, umbilical cord blood is routinely used to treat hematological and immunological diseases [21], and a well-developed network of umbilical cord blood banks around the world allows non-family use.

Mesenchymal stem/stromal cells are a heterogeneous population of multipotent cells that can differentiate into adipogenic, osteogenic, and chondrogenic directions. MSCs were first discovered in the bone marrow [22] as a part of the mononuclear fraction, where they support hematopoietic stem cells. Today they are isolated from many tissues, such as adipose tissue, placenta, umbilical cord (Wharton's jelly), muscle tissue [23]. The International Society for Cell and Gene Therapy defined the minimum criteria for MSCs [14]:

- $\quad$ adhesion to plastic in the conditions of cultivation;

- the high level of expression of surface specific markers CD 105 , $\operatorname{CD~90,CD~} 73(\geq 95 \%)$ and the low level of expression of markers CD11b, CD14, CD19, CD34, CD45, CD79a and HLA-DR ( $\leq 2 \%)$;

- $\quad$ ability to differentiate into adipocytes, chondrocytes and osteoblasts in vitro.

High prospects of MSCs for the treatment of various diseases, in particular nervous system pathology, encouraging results of experimental preclinical studies [24-27], lead to a growing interest in their implementation in clinical practice.

Neural stem cells are capable of self-reproduction or differentiation into cells of neuronal or glial lines. In the experimental work [28], it was shown that multipotent SCs, the precursors of astrocytes from the subventricular zone of mice, migrate to the cerebral cortex and ischemic periventricular area after intracerebral transplantation and acquire the immunophenotype of astrocytes. However, the complexity of their isolation in humans (present in the subventricular area of the brain) and their small number does not allow them to be widely introduced into clinical application.

Neural crest-derived multipotent stem cells (NC-MSCs), which can be isolated from the hair follicle, dental pulp, hard palate, are extremely promising in the treatment of the consequences of perinatal CNS damage [29]. Nerve crest stem cells give rise to neurons and glia of sensitive nodes, ganglia of the autonomic nervous system, Schwann cells of peripheral nerves. Studies in vitro of morphological characteristics showed that NC-MSCs have a high proliferative potential and express antigens characteristic of cells of the neural crest (Sox10, p75/CD271), neural stem cells (Sox2 and nestin), multipotent mesenchymal stem cells (CD44, CD73, CD90 and others) [30].

\section{THE TYPES OF STEM CELL TRANSPLANTATION}

\section{AND MECHANISMS OF THEIR ACTION IN CEREBRAL PALSY}

The positive effect of the use of SCs in the clinic is largely associated not only with their differentiation into the cells of damaged tissue, but also with the secretion of trophic factors [31], which have pronounced proangiogenic, neurotrophic, antiapoptotic, anti-inflammatory and immunomodulatory effects [32]. SCs from different sources differ in secretome
[33]. The most pronounced proregenerative properties are inherent in MSCs of perinatal tissues: umbilical cord, placenta and umbilical cord blood [34]. In addition, the procedure for obtaining them eliminates the need for an additional surgery, unlike the obtaining of MSCs from bone marrow or adipose tissue. The low expression of class I molecules of the main histocompatibility complex (MHC) in the absence of expression of MHC class II molecules [35], makes possible allogeneic MSCs transplantation, which is extremely important from the clinical point of view.

According to the position of the Office for sanitary inspection by the Food and Drug Administration of the USA (US Food and Drug Administration, FDA), the process of extracting the cells or tissues of the recipient organism, biotechnological manipulation with them (cultivation) and introduction in the same body would regard as available as transplantation [36]. Therefore, legally autologous and allogeneic MSCs transplantations are absolutely identical, despite the fact that allogeneic transplantation has unconditional advantages in the clinic. In diseases that affect the immune system and lead to mutations in the genome, the use of autologous SCs is not justified, due to the presence of the same disorders in themselves, so the effectiveness of their use will be low [37].

The mechanisms of positive action of SCs in CP include the improvement of nerve tissue trophism, the improvement of metabolism in it, through the action of trophic factors, the stimulation of migration, the proliferation and differentiation of endogenous progenitor cells and the stimulation of angiogenesis [38, 39].

Anti-inflammatory and immunomodulatory effects in response to brain tissue damage provide the inhibition of the pro-inflammatory cytokines release (TNF-a, IL-1 $\beta$, IFN- $\gamma$ ), free radicals and the production of anti-inflammatory cytokines (IL-10 and IL-4). Umbilical cord blood mononuclear cells can reduce the inflammatory response in the perinatal ischemic rat brain model and have immunoregulatory capacity. Tregs and monocytes are present in the normal body at a considerable level and some specific subsets of Tregs suppress T-cell proliferation. IL-4-produced Th2 cells and Tregs occurred frequently both within the brain and in peripheral tissues after SCs transplantation. SCs have the positive effect on coordination of immunomodulatory macrophage response, reduce microglial activation and protect against tissue injury [40].

After administration, stem cells migrate to tissues where degenerative and inflammatory processes occur. In the case of cerebral palsy, it is the tissue of the CNS. One of the signaling pathways for homing is the stromal-derived factor-1 (SDF-1) and C-X-C chemokine receptor type 4 (CXCR4) mediated pathway. MSCs express CXCR4, and the expression of SDF-1 after hypoxic-ischemic CNS damage increases significantly. Transplanted umbilical cord blood SCs that express receptors for SDF-1 migrate to the affected tissues within 24 hours after administration in the experiment.

MSCs realize their positive effect by secreting exosomes, vesicles containing signaling proteins, miRNAs and trophic factors. Interestingly, exosomes themselves can improve tissue trophism and have a therapeutic effect. Soluble molecules secreted by stem cells through their interaction with the membrane receptors of the recipient cells are another mechanism of action of SCs. Such molecules are granulocyte colony-stimulating factor (G-CSF), brain-produced neurotrophic factor (BDNF), granulocyte-macrophage colony-stimulating factor (GM-CSF). In the presence of BDNF, MSCs of umbilical cord blood may acquire a neural phenotype [40-42].

An important factor in the emergence of MSCs on the nervous system is the stimulation of neuroplasticity and the induction of endogenous neurogenesis. The administration of MSCs improves brain function, avoids the development of cerebral inflammation and inflammation related degeneration and prevents astrocyte proliferation. Myelin structural and functional abnormalities in brain tissue can be improved by MSCs injection. The increased expression of synaptic proteins after MSCs transplantation in the experiment, indicates the formation of new synaptic contacts [41]. Another study found the inhibition of microglia formation and stimulation of neurogenesis in an experiment [42]. 
An important place in the implementation of the positive effect of SCs on the CNS belongs to the stimulation of angiogenesis. The comparative study of the influence of embryonic nervous tissue and autologous tissue bone marrow transplantation on angiogenesis in ischemic brain damage in the experiment [43] found that bone marrow transplantation is more effective for angiogenesis stimulation in the area of ischemic brain damage than the transplantation of embryonic nervous tissue and leads to an increase in the average number of vessels in "penumbra" area of experimental animals by $215 \%$, compared with a subgroup of animals with the transplantation of embryonic nervous tissue (170\%), and control subgroup of animals (150\%) in timing between 7 and 28 days of observation. The transplantation of the bone marrow, in contrast to embryonic nervous tissue, leads to the reduction of the degree of ischemic damage in tissues of the brain in dynamics from 7 to 14 day observation that show the indicators of volume areas infarction of the brain of experimental animals: $24.6 \pm 1.9 \%$ at transplant tissue of the bone marrow, $31.7 \pm 4.4 \%$ - in the control subgroup of 14 days of observation.

CLINICAL STUDIES ON THE USE OF STEM CELLS IN CEREBRAL PALSY

On the basis of the Romodanov State Institute of Neurosurgery of NAMS of Ukraine a fundamental clinical study on the effects of embryonic neurogenic cells in CP treatment was performed [15]. Prior to treatment, clinical, electrophysiological and immunological studies were performed on 145 patients with spastic forms of cerebral palsy, aged 2 to 15 years, who were transplanted with human embryonic neurogenic cells at 8-9 weeks of gestation in the parenchyma of the cerebral cortex on both sides. It is established that neurotransplantation is an effective method of correction of motor disorders in patients with cerebral palsy. Positive dynamics in the formation of stato-kinetic functions after neurotransplantation was observed in $63 \%$ of patients with spastic tetraparesis, in $50 \%$ - with spastic diplegia in $59 \%$ - with hemiparetic form of the disease. Neurotransplantation also positively influences the course of epileptic syndrome in $70 \%$ of patients with spastic cerebral palsy - the polymorphic nature of seizures disappears, their frequency and the number reduce and the duration of clinical remission increases. With the development of new technologies, the emphasis on the use of ESCs began to shift towards iPSCs, taking into account the moral and ethical aspects. However, both cell types have the disadvantages mentioned above.

Gu et al., in a double-blind randomized controlled clinical trial [44] show that the use of umbilical cord MSCs improved motor and cognitive function in children with cerebral palsy. According to PET/CT data, in 3 out of 8 patients treated with umbilical cord MSCs, the level of glucose metabolism in the brain increased by $50 \%$. The authors indicate the safety of the procedure (in 2 of 14 patients there was an increase in body temperature to $38.5^{\circ} \mathrm{C}$, which returned to normal within 24 hours after the transplantation), no serious side effects and the presence of peak clinical effect after 6 months and its retention 12 months after administration. Immunosuppression was not performed due to the immunomodulatory ability of MSCs, which explains their effectiveness in the treatment of graft-versus-host disease [45]. The same study revealed a significant decrease in the level of proinflammatory mediators IL-1a, IL-6, TNF- $\beta$ in the blood of patients after transplantation of umbilical cord MSCs. The most pronounced clinical effect of the procedure was observed within 6 months and lasted up to 12 months after the treatment with a gradual slight decrease in the effect, which, however, did not return to baseline.

The results of the meta-analysis provided by Xie et al., transplantation of MSCs significantly improves motor function in patients with cerebral palsy, by Gross Motor Function Measure (GMFM) [46]. In addition, Wang et al. found that the hereditary factor is important for the regression of motor disorders, as of the 8 pairs of twins with cerebral palsy, who were treated with umbilical cord MSCs, showed a statistically significant improvement that correlated between twins from one pair and did not correlate between pairs [47]. Fu et al. reported the improvement in motor function in patients with cerebral palsy 6 months after umbilical cord MSCs transplantation at a dose of $4-8 \cdot 10^{7}$ that was not age-dependent (the study involved patients aged 1 month to 12 years) [48]. Adverse reactions were reported by the authors: 4 out of 57 patients had dizziness and headache, two patients had fever up to $38.5^{\circ} \mathrm{C}$, which decreased to normal within 24 hours without specific treatment.

Also, Sun et al. emphasize the need to use a sufficient dose of stem cells and indicate the feasibility of introducing at least $2 \cdot 10^{7}$ umbilical cord blood mononuclear cells per kilogram of patient weight. The same study shows that cell dose can be increased to $6 \cdot 10^{8}$ without district harm and occurrence of significant side effects [49].

Chen et al. observed the improvement in motor function in patients with cerebral palsy who received autologous bone marrow MSCs. The improvement of motor function on the Gross Motor Performance Measure (GMFM) scale was shown, without the improvement in speech [50]. In 2013 Min et al. conducted studies on the efficacy and safety of allogeneic cord blood stem cell transplantation in children with cerebral palsy [51]. The study compared three groups: 1) cord blood stem cells + erythropoietin; 2) placebo + erythropoietin; 3) double placebo. Patients in the first group had statistically significantly better results on the GMPM scale, as well as on the Bayley Scales of Infant Development (BSID-II), which assessed movements and cognitive properties 6 months after transplantation. The frequency of serious adverse reactions did not differ between groups. The results were confirmed by PET/CT, where different patterns of activation/deactivation in the CNS were detected. In 2015 Miao et al. investigated the effectiveness of the intrathecal administration of umbilical cord MSCs at neurological diseases, including CP [52]. One year after the treatment, the regression of neurological deficit was observed in $47 \%$ of patients. Side effects in the form of headache, fever, low back pain and lower extremities were affected by symptomatic treatment for 48 hours. The authors concluded that the intrathecal administration of umbilical cord MSCs is a safe way to treat patients with neurological profile.

Novak et al. conducted a meta-analysis of 4 randomized and 1 nonrandomized clinical trials on the effectiveness of stem cells of different origins for 328 children and young people ( $<32$ years) with cerebral palsy [53]. The overall risk of serious adverse reactions in the group of patients who underwent stem cell transplantation was $3 \%$, compared with $2 \%$ in the control group who were treated without the use of cell technology.

Eggenberger et al. conducted a meta-analysis of 5 studies with a total population of 282 patients ranging in age from 6 months to 35 years [54]. The authors note a statistically significant improvement in motor function in the group of patients who received stem cells, compared with the control group who received standard treatments. The high heterogeneity of patients (I2 $=90.1 \%)$ is alarming, which negatively affects the reliability of the results of the meta-analysis. The cell dose was different in the studies, but the improvement in motor function in patients correlated with a higher cell dose. In addition to improving the motor area, the authors analyzed the safety of cell technology. Only 2 studies reported serious adverse reactions. There was one case of hemorrhage in the frontal lobe of the brain after intraventricular administration of cellular material, which the study authors explained by the invasiveness of the entry procedure and unrelated to stem cells effect. Other cases of serious adverse reactions included fever and infection, which, however, were resolved after symptomatic treatment for 1-7 days after administration. The authors did not note any cases of increasing the frequency of serious adverse reactions that would correlate with increasing the dose of cells. Even with the use of stem cells in the amount of $5.97 \cdot 10^{8} / \mathrm{kg}$ body weight of the patient, no adverse reactions were recorded. Short-term results indicate the safety of MSCs transplantation in patients with cerebral palsy, but long-term results need to be studied.

Boruczkowski et al. reported an improvement in the quality of life in 49 patients out of 54 who underwent umbilical cord MSCs transplantation. 21 patients improved their ability to self-care [6]. The study included the patients of different age groups (1 year 5 months to 17 years) and weight $(7$ to $75 \mathrm{~kg}$ ). Also, patients received different doses of MSCs (1 to 5 ) and a better clinical effect was observed in the patients treated with MSCs least two $89 \cdot 10^{6} / \mathrm{kg}$. No serious side effects were observed, 3 patients had fever and mild headache, which passed without treatment. 


\section{CONCLUSION}

The use of regenerative cell technologies in the treatment of patients with cerebral palsy is extremely promising. Numerous experimental studies have significantly expanded the understanding of the mechanisms of the stem cells effect in cerebral palsy treatment. Clinical applications of stem cells of different origins confirm the safety of the method. However, like any new method of treatment, it requires further study, research with indepth analysis of the impact of stem cells in cerebral palsy and the definition of long-term treatment outcomes.

\section{REFERENCES}

1. Nakaz MOZ № 286 vid 09.04 .2013 p. “Pro zatverdzhennya ta vprovadzhennya mediko-tekhnologichnih dokumentiv zi standartizaciï medichnoï dopomogi pri organichnih urazhennyah golovnogo mozku u ditej, yaki suprovodzhuyut'sya ruhovimi porushennyami” [in Ukrainian]

2. Kabacij M. S. Goshko V. Yu.; Seker T. M. Likuvannya spasty`chny`x form dy tyachogo cerebral’nogo paralichu v ditej na etapax operaty vnogo vtruchannya. Travma 2016; 17(3): 166-168. doi:10.22141/1608-1706.3.17.2016.75803 [in Ukrainian].

3. Gulati S, Sondhi V. Cerebral Palsy: An Overview. Indian J Pediatr. 2018; 85(11):1006-1016. D0l:10.1007/s12098-017-2475-1.

4. Lee FK, Lin YL, Wang PH. Mesenchymal stem cells and cerebral palsy. J Chin Med Assoc. 2020;83(4):323-324. D0l:10.1097/JCMA.0000000000000263.

5. Fu X, Hua R, Wang $X$, et al. Synergistic Improvement in Children with Cerebral Palsy Who Underwent Double-Course Human Wharton's Jelly Stem Cell Transplantation. Stem Cells Int. 2019; 2019:7481069. DOl:10.1155/2019/7481069.

6. Boruczkowski D, Zdolińska-Malinowska I. Wharton's Jelly Mesenchymal Stem Cell Administration Improves Quality of Life and Self-Sufficiency in Children with Cerebral Palsy: Results from a Retrospective Study. Stem Cells Int. 2019; 2019:7402151. DOl:10.1155/2019/7402151.

7. Nitkin CR, Rajasingh J, Pisano C, Besner GE, Thébaud B, Sampath V. Stem cell therapy for preventing neonatal diseases in the 21 st century: Current understanding and challenges. Pediatr Res. 2020; 87(2):265-276. D0l:10.1038/s41390-019-0425-5.

8. Chang YS, Ahn SY, Sung S, Park WS. Stem Cell Therapy for Neonatal Disorders: Prospects and Challenges. Yonsei Med J. 2017; 58(2):266-271. D0l:10.3349/ ymj.2017.58.2.266.

9. Domenighetti AA, Mathewson MA, Pichika R, et al. Loss of myogenic potential and fusion capacity of muscle stem cells isolated from contractured muscle in children with cerebral palsy. Am J Physiol Cell Physiol. 2018; 315(2):C247-C257. D0l:10.1152/ajpcell.00351.2017.

10. Zakrzewski W, Dobrzyński M, Szymonowicz M, Rybak Z. Stem cells: past, present, and future. Stem Cell Res Ther. 2019; 10(1):68. D0l:10.1186/s13287-019$1165-5$.

11. Suman S, Domingues A, Ratajczak J, Ratajczak MZ. Potential Clinical Applications of Stem Cells in Regenerative Medicine. Adv Exp Med Biol. 2019; 1201:1-22. DOl:10.1007/978-3-030-31206-0_1.

12. Laplane L, Solary E. Towards a classification of stem cells. Elife. 2019; 8:e46563. D0l:10.7554/eLife.46563

13. Rameshwar P, Moore CA, Shah NN, Smith CP. An Update on the Therapeutic Potential of Stem Cells. Methods Mol Biol. 2018; 1842:3-27. D0l:10.1007/978-14939-8697-2_1.

14. Viswanathan S, Shi Y, Galipeau J, et al. Mesenchymal stem versus stromal cells: International Society for Cell \& Gene Therapy (ISCT®) Mesenchymal Stromal Cell committee position statement on nomenclature. Cytotherapy. 2019; 21(10):1019-1024. D0I:10.1016/j.jcyt.2019.08.002

15. Pichkur L.D. Nejrohirurgichne likuvannya hvorih na dityachij cerebral'nij paralich [disertaciya]. Kiïv (Ukraïna): DU «Institut nejrohirurgiï im. akad. A.P.Romodanova NAMN Ukraïni»; 2009 [in Ukrainian].

16. Ben-David U, Benvenisty N. The tumorigenicity of human embryonic and induced pluripotent stem cells. Nat Rev Cancer. 2011; 11(4):268-277. D0l:10.1038/ nrc3034.

17. Takahashi K, Tanabe K, Ohnuki $M$, et al. Induction of pluripotent stem cells from adult human fibroblasts by defined factors. Cell. 2007; 131(5):861-872. DOl:10.1016/j.cell.2007.11.019.

18. Godini R, Lafta HY, Fallahi H. Epigenetic modifications in the embryonic and induced pluripotent stem cells. Gene Expr Patterns. 2018; 29:1-9. D0l:10.1016/j. gep.2018.04.001.

19. Berglund S, Magalhaes I, Gaballa A, Vanherberghen B, Uhlin M. Advances in umbilical cord blood cell therapy: the present and the future. Expert Opin Biol Ther. 2017; 17(6):691-699. DOl:10.1080/14712598.2017.1316713.

20. Ruggeri A, Paviglianiti A, Gluckman E, Rocha V. Impact of HLA in cord blood transplantation outcomes. HLA. 2016; 87(6):413-421. D0l:10.1111/tan.12792.

21. Cavusoglu T, Kilic KD, Yigitturk G, Tomruk C, Turgut M, Uyanikgil Y. Clinical Use and Patentability of Cord Blood. Recent Pat Endocr Metab Immune Drug Discov. 2017; 11(1):13-21. DOI:10.2174/1872214812666180314121241.

22. Polymeri A, Giannobile WV, Kaigler D. Bone Marrow Stromal Stem Cells in Tissue Engineering and Regenerative Medicine. Horm Metab Res. 2016; 48(11):700713. DOl:10.1055/s-0042-118458.

23. Lagarkova MA. Such Various Stem Cells. Biochemistry (Mosc). 2019; 84(3):187-189. D0l:10.1134/S0006297919030015.

24. Galipeau J, Sensébé L. Mesenchymal Stromal Cells: Clinical Challenges and Therapeutic Opportunities. Cell Stem Cell. 2018; 22(6):824-833. D0l:10.1016/j. stem.2018.05.004.

25. Fu X, Liu G, Halim A, Ju Y, Luo Q, Song AG. Mesenchymal Stem Cell Migration and Tissue Repair. Cells. 2019; 8(8):784. D0l:10.3390/cells8080784.

26. Guadix JA, Zugaza JL, Gálvez-Martín P. Characteristics, applications and prospects of mesenchymal stem cells in cell therapy. Características, aplicaciones y perspectivas de las células madre mesenquimales en terapia celular. Med Clin (Barc). 2017; 148(9):408-414. D0l:10.1016/j.medcli.2016.11.033.

27. Marofi $F$, Vahedi $G$, Hasanzadeh $A$, et al. Mesenchymal stem cells as the game-changing tools in the treatment of various organs disorders: Mirage or reality? J Cell Physiol. 2019; 234(2):1268-1288. D0l:10.1002/jcp.27152.

28. Shigemoto-Mogami Y, Hoshikawa K, Goldman JE, Sekino Y, Sato K. Microglia enhance neurogenesis and oligodendrogenesis in the early postnatal subventricular zone. J Neurosci. 2014; 34(6):2231-2243. DOI:10.1523/JNEUROSCI.1619-13.2014. 
29. Liu JA, Cheung M. Neural crest stem cells and their potential therapeutic applications. Dev Biol. 2016; 419(2):199-216. D0I:10.1016/j.ydbio.2016.09.006.

30. Kosykh A, Beilin A, Sukhinich K, Vorotelyak E. Postnatal neural crest stem cells from hair follicle interact with nerve tissue in vitro and in vivo. Tissue Cell. 2018; 54:94-104. DOI:10.1016/j.tice.2018.08.005.

31. Hofer HR, Tuan RS. Secreted trophic factors of mesenchymal stem cells support neurovascular and musculoskeletal therapies. Stem Cell Res Ther. 2016 ; 7(1):131. DOI:10.1186/s13287-016-0394-0

32. Wang S, Zhu R, Li H, Li J, Han Q, Zhao RC. Mesenchymal stem cells and immune disorders: from basic science to clinical transition. Front Med. 2019; 13(2):138151. D0I:10.1007/s11684-018-0627-y.

33. Fu Y, Karbaat L, Wu L, Leijten J, Both SK, Karperien M. Trophic Effects of Mesenchymal Stem Cells in Tissue Regeneration. Tissue Eng Part B Rev. 2017; 23(6):515-528. DOI:10.1089/ten.TEB.2016.0365.

34. Abbaspanah B, Momeni M, Ebrahimi M, Mousavi SH. Advances in perinatal stem cells research: a precious cell source for clinical applications. Regen Med. 2018; 13(5):595-610. DOI:10.2217/rme-2018-0019

35. Ma T, Wang X, Jiang D. Immune Tolerance of Mesenchymal Stem Cells and Induction of Skin Allograft Tolerance. Curr Stem Cell Res Ther. $2017 ; \mathbf{1 2 ( 5 ) : 4 0 9 - 4 1 5 . ~}$ DOI:10.2174/1574888X12666170301122744.

36. Chirba MA, Sweetapple B, Hannon CP, Anderson JA. FDA regulation of adult stem cell therapies as used in sports medicine. J Knee Surg. 2015; 28(1):55-62. DOI:10.1055/s-0034-1398470.

37. Wang Y, Tian M, Wang F, et al. Understanding the Immunological Mechanisms of Mesenchymal Stem Cells in Allogeneic Transplantation: From the Aspect of Major Histocompatibility Complex Class I. Stem Cells Dev. 2019; 28(17):1141-1150. D0I:10.1089/scd.2018.0256.

38. Li N, Hua J. Interactions between mesenchymal stem cells and the immune system. Cell Mol Life Sci. 2017; 74(13):2345-2360. D0I:10.1007/s00018-017-2473-5.

39. Kiaie N, Aghdam RM, Tafti SHA, Gorabi AM. Stem Cell-Mediated Angiogenesis in Tissue Engineering Constructs. Curr Stem Cell Res Ther. $2019 ; 14(3): 249-258$. DOI:10.2174/1574888X13666181105145144

40. Munir H, Ward LSC, McGettrick HM. Mesenchymal Stem Cells as Endogenous Regulators of Inflammation. Adv Exp Med Biol. 2018; 1060:73-98. D0I:10.1007/9783-319-78127-3_5.

41. Ko HR, Ahn SY, Chang YS, et al. Human UCB-MSCs treatment upon intraventricular hemorrhage contributes to attenuate hippocampal neuron loss and circuit damage through BDNF-CREB signaling. Stem Cell Res Ther. 2018; 9(1):326. D0I:10.1186/s13287-018-1052-5.

42. Gobshtis $N$, Tfilin M, Wolfson M, Fraifeld VE, Turgeman G. Transplantation of mesenchymal stem cells reverses behavioural deficits and impaired neurogenesis caused by prenatal exposure to valproic acid. Oncotarget. 2017; 8(11):17443-17452. DOl:10.18632/oncotarget.15245.

43. YarmolyukE.S. Vpliv tkaninnoï transplantaciï na angiogenez v dilyanci ishemichnogo ushkodzhennya golovnogo mozku v eksperimenti [disertaciya]. Kiïv (Ukraïna): Institut nejrohirurgiï im. akad. A. P. Romodanova NAMN Ukraïni; 2016 [in Ukrainian].

44. Gu J, Huang L, Zhang C, et al. Therapeutic evidence of umbilical cord-derived mesenchymal stem cell transplantation for cerebral palsy: a randomized, controlled trial. Stem Cell Res Ther. 2020; 11(1):43. DOl:10.1186/s13287-019-1545-X.

45. Elgaz S, Kuçi Z, Kuçi S, Bönig H, Bader P. Clinical Use of Mesenchymal Stromal Cells in the Treatment of Acute Graft-versus-Host Disease. Transfus Med Hemother. 2019; 46(1):27-34. DOI:10.1159/000496809.

46. Xie B, Chen M, Hu R, Han W, Ding S. Therapeutic Evidence of Human Mesenchymal Stem Cell Transplantation for Cerebral Palsy: A Meta-Analysis of Randomized Controlled Trials. Stem Cells Int. 2020; 2020:5701920. D0I:10.1155/2020/5701920/

47. Wang $X, \mathrm{Hu} \mathrm{H}$, Hua $\mathrm{R}$, et al. Effect of umbilical cord mesenchymal stromal cells on motor functions of identical twins with cerebral palsy: pilot study on the correlation of efficacy and hereditary factors. Cytotherapy. 2015; 17(2):224-231. D0I:10.1016/j.jcyt.2014.09.010/

48. Fu X, Hua $R$, Wang $X$, et al. Synergistic Improvement in Children with Cerebral Palsy Who Underwent Double-Course Human Wharton's Jelly Stem Cell Transplantation. Stem Cells Int. 2019; 2019:7481069. DOI:10.1155/2019/7481069.

49. Sun JM, Song AW, Case LE, et al. Effect of Autologous Cord Blood Infusion on Motor Function and Brain Connectivity in Young Children with Cerebral Palsy: A Randomized, Placebo-Controlled Trial. Stem Cells Transl Med. 2017; 6(12):2071-2078. D0I:10.1002/sctm.17-0102/

50. Chen $G$, Wang $Y, X u Z$, et al. Neural stem cell-like cells derived from autologous bone mesenchymal stem cells for the treatment of patients with cerebral palsy. J Transl Med. 2013; 11:21. D0I:10.1186/1479-5876-11-21.

51. Min K, Song J, Kang JY, et al. Umbilical cord blood therapy potentiated with erythropoietin for children with cerebral palsy: a double-blind, randomized, placebocontrolled trial. Stem Cells. 2013; 31(3):581-591. D0I:10.1002/stem.1304.

52. Miao X, Wu X, Shi W. Umbilical cord mesenchymal stem cells in neurological disorders: A clinical study. Indian J Biochem Biophys. $2015 ; \mathbf{5 2 ( 2 ) : 1 4 0 - 1 4 6 . ~}$

53. Novak I, Walker K, Hunt RW, Wallace EM, Fahey M, Badawi N. Concise Review: Stem Cell Interventions for People With Cerebral Palsy: Systematic Review With Meta-Analysis. Stem Cells TransI Med. 2016; 5(8):1014-1025. D0I:10.5966/sctm.2015-0372.

54. Eggenberger S, Boucard C, Schoeberlein A, et al. Stem cell treatment and cerebral palsy: Systemic review and meta-analysis. World J Stem Cells. 2019; 11(10):891903. DOI:10.4252/wjsc.v11.i10.891.

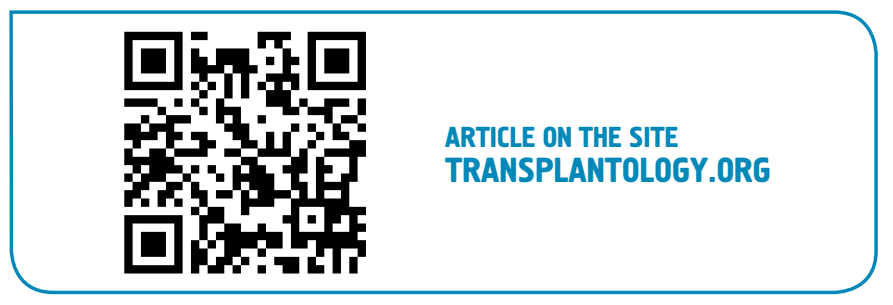

The authors declared no potential conflicts of interest with respect to the research, authorship, and/or publication of this article. 


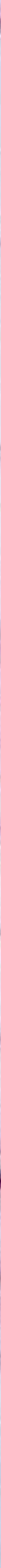

